\title{
Translation and validation into Brazilian Portuguese of the Spastic Paraplegia Rating Scale (SPRS)
}

\author{
Tradução e validação da escala de classificação de paraplegia espástica (SPRS) para a \\ versão brasileira
}

Katiane R. Servelhere, Ingrid Faber, Ana Carolina Coan, Marcondes França Junior

\begin{abstract}
Hereditary spastic paraplegias (HSP) are characterized by progressive lower limb weakness and spasticity. There are no validated instruments to quantify disease severity in Portuguese. Objective: To translate and validate the Spastic Paraplegia Rating Scale (SPRS) into Brazilian-Portuguese. Method: Two experienced and English-fluent neurologists translated SPRS into Portuguese, creating SPRS-BR. We then assessed inter and intra-rater reliability of this version using coefficients of correlation and variability in a cohort of 30 patients. Results: Mean age of patients and disease duration were $47.7 \pm 10.5$ and $17.0 \pm 10.6$ years, respectively. Twenty-one had pure HSP and SPG 4 was the most frequent genotype. Mean Rankin and SPRS-BR scores were $2.2 \pm 0.9$ and $19.9 \pm 9.9$, respectively. Mean intra and inter-rater correlation coefficients of SPRS-BR scores were 0.951 and 0.934 , whereas coefficients of variation were 11.5\% (inter-rater) and $9.9 \%$ (intra-rater). Cronbach's alpha for the whole SPRS-BR scale was 0.873. Conclusion: SPRS-BR is a useful, reliable and valid clinical instrument.
\end{abstract}

Keywords: spastic paraplegia, hereditary; scales; tranlating.

\section{RESUMO}

As paraparesias espásticas hereditárias (PEH) apresentam progressiva espasticidade e fraqueza dos membros inferiores. Não existem escalas validadas em língua portuguesa para quantificar a gravidade da doença. Objetivo: Traduzir e validar para o português do Brasil a Spastic Paraplegia Rating Scale (SPRS). Método: Dois neurologistas experientes em neurogenética e fluentes em inglês traduziram a SPRS para o português, criando a SPRS-BR. Em seguida, checamos a reprodutibilidade da escala usando coeficientes de correlação e variabilidade em um grupo de 30 pacientes. Resultados: As médias de idade e duração de doença foram de 47,7 \pm 10,5 e 17,0 $\pm 10,6$ anos, respectivamente. Vinte e um eram portadores da forma pura de PEH, sendo que SPG4 foi o genótipo mais frequente. A pontuação das escalas Rankin e SPRS-BR foi, respectivamente, 2,2 \pm 0,9 e 19,9 9 9,9. Os coeficientes de correlação inter e intraexaminador da SPRS-BR foram 0,934 e 0,951, enquanto que os coeficientes de variação foram de 11,5\% (interexaminador) e 9,9\% (intraexaminador). 0 coeficiente alfa de Cronbach's para a escala SPRS-BR foi de 0.873. Conclusão: A SPRS-BR é uma escala útil clinicamente, fácil de aplicar e que apresentou boa reprodutibilidade e validade.

Palavras-chave: paraplegia espástica hereditária; escalas; tradução.

Hereditary spastic paraplegias (HSP) are a heterogeneous group of heredodegenerative disorders, characterized by progressive and retrograde degeneration of the corticospinal tracts in the spinal cord ${ }^{1,2,3,4}$. To date, there are more than 70 genetic types described ${ }^{5}$. The core clinical features of HSP are slowly progressive spasticity and weakness of the lower limbs. In pure HSP, patients present essentially with a spastic gait, but they may also have urinary incontinence and deep sensory abnormalities in the legs. In contrast, patients with complicated forms of HSP have other associated manifestations, such as dementia, peripheral neuropathy, parkinsonism and ataxia.

Patients with HSP often have a slow disease progression, but the clinical course may be different even for patients with the same genetic background. Therefore, it is important to apply standardized and validated instruments to assess disease severity in the long term. In addition, clinical trials directed towards HSP will need robust clinical scales to assess the efficacy of treatments. In this scenario, the German Network for Hereditary Movement Disorders (GeNeMove) developed and

Universidade de Campinas, Departamento de Neurologia, Campinas SP, Brasil.

Correspondence: Marcondes C. França Junior; Departamento de Neurologia, Universidade de Campinas; R. Tessália Vieira de Camargo, 126 ; $13083-887$ Campinas SP, Brasil; E-mail: mcfrancajr@uol.com.br

Conflict of interest: There is no conflict of interest to declare.

Received 04 December 2015; Received in final form 3 February 2016; Accepted 24 February 2016. 
validated a scale that rates functional impairment, focusing on the key features of pure spastic paraplegias: the Spastic Paraplegia Rating Scale (SPRS). This tool is easy to use in the clinic, and presented good reliability and validity as a measure of disease severity ${ }^{6}$. Several studies employed SPRS in cohorts of patients with $\mathrm{HSP}^{3,7,8,9,10}$. Taking into account that there are no such instruments available in our language, we designed this study to validate the Brazilian Portuguese version of SPRS. We believe that such an instrument would optimize the clinical care of our patients not only with HSP but also with other chronic myelopathies.

\section{METHOD}

\section{Translation of SPRS and cultural adaptation}

SPRS has thirteen items that include: walking distance without pause; gait quality; maximum gait speed; climbing stars; arising from chair; spasticity of hip adductor and knee flexion muscles; weakness of hip abduction and foot dorsiflexion; contracture of lower limbs; pain related to spasticity and bladder and bowel function. Each item has a score ranging from 0 to 4, where 0 represents no dysfunction and 4 represents most severe dysfunction. The score result is calculated by adding single scores of each of the 13 items ${ }^{6}$. Therefore, SPRS total score varies between 0 (no dysfunction) and 52 (most severe dysfunction).

Two board-certified Brazilian neurologists, fluent in English and experienced in the care of patients with hereditary spastic paraplegia translated SPRS into Portuguese. This process resulted in two forward translations: versions 1 and 2. The translators discussed the translations and the consensus resulted in a reconciled version (version 3). Subsequently, another researcher fluent in English back translated the reconciled version into the English language, resulting in version 4 of the scale. Versions 3 and 4 were then assessed by the authors, through the comparison with the original text for the correction of discrepancies and creation of a consensus final version (SPRS-BR) - Appendix.

We then assessed inter and intra-rater reliability of SPRS-BR. This was done through the evaluation of 30 adult patients with clinical and/or molecular confirmation of HSP in two stages, by 2 experienced researchers, and using coefficients of correlations and variability. For each patient, we also applied the Rankin scale ${ }^{11}$. This was done to investigate whether SPRS-BR scores correlate with this measure of independence for activities of daily living.

The study was approved by our institution ethics committee. Written informed consent was obtained from all patients prior to any study-related procedure.

\section{Statistical analyses}

For each patient, we recorded data on age, age at onset, disease duration, gender, SPRS and Rankin total scores, inheritance pattern, genotype, need for walking assistive devices and time interval between examinations. These data are shown with descriptive statistics: categorical variables expressed as relative frequency (\%) and numerical variables expressed as mean $\pm \mathrm{SD}$.

To assess the internal consistency of SPRS-BR, we used the Cronbach's alpha coefficient, and considered values higher than 0.8 indicating good consistency.

To assess intra and inter-rater reliability of SPRS-BR, we performed 2 different analyses. We first used Spearman coefficients to assess the correlation of SPRS-BR scores performed by the same evaluator in 2 distinct days (intra-rater) and by 2 different evaluators in the same day (inter-rater). We then explored intra and inter-rater variability of SPRS-BR scores using coefficients of variation (CV). These were calculated as

$S D=\sum \sqrt{\frac{(x 1-x 2)^{2}}{2 n}}$, Mean $=\sum \frac{x 1+x 2}{2 n}$ and $C V(\%)=100 X \frac{S D}{\text { Mean }}$. where $\mathrm{n}$ is the number of patients (30), $\mathrm{x} 1$ and $\mathrm{x} 2$ are the scores obtained for different examiners (or the same examiner in different days).

The statistical analyses were performed using software systat 12.0 .

\section{RESULTS}

We evaluated 30 adult patients with pure and complicated HSP that were regularly followed at the neurogenetics clinic at UNICAMP. Sixteen patients were able to walk unassisted, 10 needed some walking assistive device (Canadian crutches, canes and/or walkers) and 4 patients were wheelchair bound and did not walk at all. Mutations in the SPAST gene were identified in $40 \%$ of HSP patients in this cohort. Further demographic and genetic data of the patients included in this study are shown in Table 1.

Application of SPRS-BR took around 10-15 minutes and did not require any special equipment. The examiners 1 (KRS) and 2 (IF) performed the first evaluation separately, but in the same day. Then, examiner 1 performed an additional evaluation after 31 days on average, to assess intra-rater reliability. Taking into account that HSP are slowly progressive disorders, we believe that no significant score change due to true disease worsening is supposed to take place in this short time frame.

Patients with complicated HSP had higher SPRS-BR scores than patients with pure HSP (27.4 \pm 8.9 vs $16.7 \pm 8.6, \mathrm{p}=0.0064)$. SPRS-BR scores obtained from examiner 1 at 2 different moments were highly correlated (Spearman $\mathrm{p}=0.95$ ); the same finding took place regarding SPRS-BR scores obtained from examiners 1 and 2 (Spearman $\mathrm{p}=0.93$ ) - Table 2. Intra-rater and inter-rater CV were $9.9 \%$ and $11.5 \%$, respectively. Cronbach's alpha for all questions was 0.87 , thus indicating a good internal consistency. When patients were categorized according to Rankin scores, we were able to see that SPRS-BR scores clearly increased in parallel to Rankin scores (Figure). 
Table 1. Demographic and clinical data of patients with hereditary spastic paraplegia included in this study.

\begin{tabular}{lc}
\hline Gender (M/F) & $14 / 16$ \\
\hline Phenotype & \\
$\quad$ Pure (\%) & $21(70 \%)$ \\
$\quad$ Complicated (\%) & $9(30 \%)$ \\
\hline Inheritance pattern & \\
$\quad$ Autosomal dominant (\%) & $21(70 \%)$ \\
$\quad$ Autosomal recessive (\%) & $9(30 \%)$ \\
Genotype & \\
$\quad$ SPG4 & $12(40 \%)$ \\
$\quad$ SPG11 & $2(7 \%)$ \\
$\quad$ Other & $16(53 \%)$ \\
\hline Age (mean \pm SD, years) & $47.7 \pm 10.5$ \\
Age at onset (mean \pm SD, years ) & $30.8 \pm 14.4$ \\
Disease duration (mean \pm SD, years ) & $17.0 \pm 10.6$ \\
\hline Interval between examinations (mean \pm SD, days) & $31.4 \pm 23.8$ \\
Rankin Score (mean \pm SD ) & $2.2 \pm 0.9$ \\
SPRS total score (mean \pm SD) & $19.9 \pm 9.9$ \\
\hline SPRS: spatic paraplegiatin scale.
\end{tabular}

SPRS: spatic paraplegia retina scale.

Table 2. Correlation analyses using Spearman coefficients showing inter-rater (first column) and intra-rater (second column) reliability.

\begin{tabular}{lcc}
\hline SPRS-BR Itens & Inter-rater & Intra-rater \\
\hline Q1 & 0.766 & 0.854 \\
Q2 & 0.885 & 0.913 \\
Q3 & 0.924 & 0.954 \\
Q4 & 0.924 & 0.951 \\
Q5 & 0.860 & 0.929 \\
Q6 & 0.687 & 0.781 \\
Q7 & 0.646 & 0.804 \\
Q8 & 0.598 & 0.760 \\
Q9 & 0.770 & 0.902 \\
Q10 & 0.808 & 0.805 \\
Q11 & 0.544 & 0.711 \\
Q13 & 0.645 & 0.753 \\
Total & 0.745 & 0.898 \\
\hline
\end{tabular}

\section{DISCUSSION}

SPRS is an instrument easy to apply that takes no longer than 10-15 minutes to complete. It is suitable for use both for research and for routine care of patients with HSP. Our Brazilian Portuguese version of the scale - SPRS-BR - presented good internal consistency, as well as intra and inter-rater reliability. Furthermore, it presented a clear correlation with

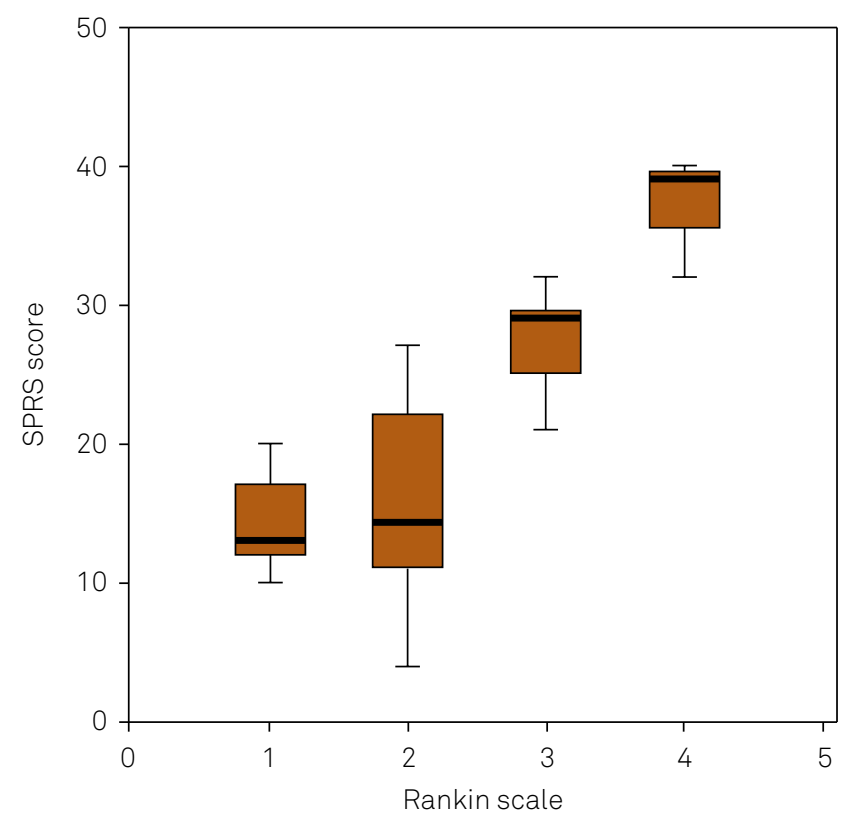

SPRS: spastic paraplegia rating scale.

Figure. Box plot showing the distribution of SPRS scores according to the Rankin scale groups.

the Rankin score, which is a standard measure of functional impairment for neurological patients. Taken together, these data suggest that SPRS-BR is a robust instrument for clinical use that will help neurologists involved in the care not only of patients with HSP but also of patients with other forms of chronic myelopathies, such as tropical spastic paraplegia and subacute combined degeneration of the spinal cord ${ }^{12,13}$.

In this validation study, we included patients with different genotypes presenting both pure and complicated phenotypes of HSP. We opted to do so in order to assess the whole phenotypic spectrum of HSP. Overall, patients with complicated HSP had higher SPRS-BR scores than pure HSP, which is in agreement with the more widespread neurological impairment they have. In terms of clinical application, SPRS-BR was easy to perform both for pure and complicated HSP. In a similar way, when we considered only complicated HSP, the parameters of intra and inter-rater reliability were both high ( $\mathrm{p}=0.962$ and 0.912 , respectively). We must acknowledge, however, that only adults were evaluated in this study (older than 18 years), so that we cannot ascertain that SPRS-BR is adequate and reliable to use in children with HSP. This needs to be investigated in future studies.

\section{References}

1. Fink JK. Hereditary spastic paraplegia: clinico-pathologic features and emerging molecular mechanisms. Acta Neuropathol. 2013;126(3):307-28. doi:10.1007/s00401-013-1115-8

2. Reid E. Pure hereditary spastic paraplegia.J Med Genet. 1997;34(6):499-503. doi:10.1136/jmg.34.6.499

3. Klimpe S, Schüle R, KassubekJ, Otto S, Kohl Z, Klebe S et al. Disease severity affects quality of life of hereditary spastic paraplegia patients. Eur J Neurol. 2012;19(1):168-171. doi:10.1111/j.1468-1331.2011.03443.x
4. Faber I, Servelhere KR, Martinez ARM, D’Abreu A, Lopes-Cendes I, França MC Jr. Clinical features and management of hereditary spastic paraplegia. Arq Neuropsiquiatr. 2014;72(3):219-26. doi:10.1590/0004-282X20130248

5. Lo Giudice T, Lombardi F, Santorelli FM, Kawarai T, Orlacchio A. Hereditary spastic paraplegia: clinical-genetic characteristics and evolving molecular mechanisms. Exp Neurol. 2014;261:518-39. doi:10.1016/j.expneurol.2014.06.011 
6. Schüle R, Holland-Letz T, Klimpe S, Kassubek J, Klopstock T, Mall V et al. The Spastic Paraplegia Rating Scale: a reliable and valid measure of disease severity. Neurology. 2006;67(3):430-4. doi:10.1212/01.wnl.0000228242.53336

7. Béreau M, Anheim M, Chanson JB, Tio G, Echaniz-Laguna A, Depienne $C$ et al. Dalfampridine in hereditary spastic paraplegia: a prospective open study. J Neurol. 2015;262(5):1285-8. doi:10.1007/s00415-015-7707-6

8. Lindig T, Bender B, Hauser TK, Mang S, Schweikardt D, Klose U et al. Gray and white matter alterations in hereditary spastic paraplegia type SPG4 and clinical correlations. J Neurol. 2015;262(8):1961-71. doi:10.1007/s00415-015-7791-7

9. Orsucci D, Petrucci L, lenco EC, Chico L, Simi P, Fogli A et al. Hereditary spastic paraparesis in adults: a clinical and genetic perspective from Tuscany. Clin Neurol Neurosurg. 2014;120:14-9. doi:10.1016/j.clineuro.2014.02.002
10. Rezende TJ, Albuquerque M, Lamas GM, Martinez AR, Campos BM, Casseb RF et al. Multimodal MRI-based study in patients with SPG4 mutations. PLoS One. 2015;10(2):e0117666. doi:10.1371/journal.pone.0117666

11. Wilson JT, Hareendran A, Grant M, Baird T, Schulz UG, Muir KW et al. Improving the Assessment of outcomes in stroke: use of a structured interview to assign grades on the modified rankin scale. Stroke. 2002;33(9):2243-6. doi:10.1161/01.STR.0000027437.22450.BD

12. Tavares IR, Franzoi AC, Araújo AQ-C. Low-back pain in HTLV-I-associated myelopathy/tropical spastic paraparesis: nociceptive or neuropathic? Spinal Cord. 2010;48(2):134-7. doi:10.1038/sc.2009.83

13. Castro-Costa CM, Araújo AQ, Câmara CC, Ferreira AS, Santos TJ, Castro-Costa SB et al. Pain in tropical spastic paraparesis/ HTLV-I associated myelopathy patients. Arq Neuropsiquiatr. 2009;67(3B):866-70. doi:10.1590/S0004-282X2009000500016 
(1) Distância que caminha sem pausa

De acordo com a história, dispositivos auxiliares são permitidos

0: Normal, ilimitada

1: Cansaço anormal devido à espasticidade após mais de $500 \mathrm{~m}$

2: Caminha menos de $500 \mathrm{~m}$

3: Caminha menos de $10 \mathrm{~m}$

4: Incapaz de andar

(2) Qualidade da marcha

É solicitado ao paciente andar o mais rápido possível uma distância de 10 metros, incluindo uma volta

0: Normal

1: Rigidez leve, correr ainda é possível

2: Marcha claramente espástica, interferindo no correr

3: Marcha espástica, com necessidade de dispositivos auxiliares

4: Incapaz de andar uma distância de 10 metros mesmo com apoio máximo

\section{(3) Velocidade máxima da marcha}

Tempo cronometrado para uma distância de 10 metros, incluindo uma volta.

0: Normal

1: Levemente reduzida(10m: $\geq 5 \mathrm{~s})$

2: Moderadamente reduzida $(10 \mathrm{~m}: \geq 10 \mathrm{~s})$

3: Gravemente reduzida(10m: $\geq 20 \mathrm{~s})$

4: Incapaz de andar uma distância de $10 \mathrm{~m}$ ou tempo $\geq 40 \mathrm{~s}$

\section{(4) Subir escadas}

\section{Subir 5 degraus-volta/giro-descer 5 degraus}

0: Normal: não necessita apoio do corrimão

1: Incapacidade leve: necessita de apoio intermitente do corrimão

2: Incapacidade moderada: necessita de apoio contínuo do corrimão

3: Incapacidade grave: necessita de apoio/suporte de outra pessoa ou dispositivo adicional para realizar a tarefa

4: Incapaz de subir escadas

\section{(5) Velocidade para subir escadas}

Tempo cronometrado para subir 5 degraus - volta/giro descer 5 degraus

0 : Normal

1: Levemente reduzida $(\geq 5 \mathrm{~s}$ para realizar a tarefa)

2: Moderadamente reduzida( $\geq 10$ s para realizar a tarefa)

3: Gravemente reduzida( $\geq 20$ s para realizar a tarefa)

4: Incapaz de subir escadas

\section{(6) Levantar-se da cadeira}

o paciente tenta se levantar de uma cadeira de madeira ou metal e encosto reto, com os braços cruzados sobre o peito

0 : Normal

1: Lento ou pode necessitar de mais de uma tentativa.

2: Levanta-se com apoio dos braços da cadeira.

3: Tende a cair para trás e pode necessitar de mais de uma tentativa, mas pode se levantar sem ajuda.

4: Incapaz de se levantar sem ajuda.

\section{(7) Espasticidade -músculos adutores do quadril} (Escala Modificada de Ashworth)

Pontue o lado mais afetado

0: Tônus muscular normal

1: Leve aumento de tônus muscular, manifestado por tensão momentânea

2: Aumento mais marcante do tônus muscular durante a maior parte da amplitude de movimento

3: Considerável aumento do tônus muscular - movimento passível é difícil

4: Membro fixo em adução

\section{(8) Espasticidade -flexão do joelho (Escala} Modificada de Ashworth)

Pontue o lado mais afetado

0: Tônus muscular normal

1: Leve aumento de tônus muscular, manifestado por tensão momentânea

2: Aumento mais marcante do tônus muscular durante a maior parte da amplitude de movimento

3: Considerável aumento do tônus muscular - movimento passível é difícil

4: Membro fixo emflexão ou extensão

(9) Fraqueza-abdução do quadril (Medical Research Council 1976)

0 : Sem fraqueza

1: Fraqueza leve (4/5)

2: Fraqueza moderada (3/5)

3: Fraqueza grave (1-2/5)

4: Plegia $(0 / 5)$

(10) Fraqueza-dorsiflexão do pé (Medical Research Council 1976)
0: Sem fraqueza
1: Fraqueza leve $(4 / 5)$
2: Fraqueza moderada $(3 / 5)$
3: Fraqueza grave $(1-2 / 5)$
4: Plegia $(0 / 5)$ 
(11) Contraturas dos membros inferiores

Pontue na posição supina

- Extensão de quadril: coluna lombar e coxas tocam a superfície. Abdução de quadril: abdução até um ângulo $>60^{\circ}$ entre as pernas é possivel

- Extensão de joelhos: coxas e panturrilhas tocam a superfície.

- Extensão dorsal do tornozelo: $>10^{\circ}$ é possível. Pronação

do tornozelo : $>10^{\circ}$ é possível

0 : Sem contraturas

1: Leve, posição anormal não fixa de uma articulação (unilateral ou bilateral)

2: Contratura fixa de uma articulação (unilateral ou bilateral)

3: Contratura fixa de duas articulações (unilateral ou bilateral)

4: Contratura fixa de mais de duas articulações (unilateral ou bilateral)
(12) Dor secundária a sintomas relacionados à paraplegia espástica

0 : Sem dor

1: Presente em $\leq 50 \%$ do dia enquanto acordado $\mathrm{E}$ intensidade 0 - 3 pontos na escala visual analógica

2: Presente em $\leq 50 \%$ do dia enquanto acordado $\mathrm{E}$ intensidade 4 - 10 pontos na escala visual analógica

3: Presente em $>50 \%$ do dia enquanto acordado $E$ intensidade 0 - 3 pontos na escala visual analógica

4: Presente em $>50 \%$ do dia enquanto acordado $\mathrm{E}$ intensidade 4 - 10 pontos na escala visual analógica

(13) Função vesical e intestinal

0: Função vesical e intestinal normais

1: Urgência urinária ou fecal (dificuldade de chegar ao banheiro a tempo)

2: Urge incontinência rara e leve (sem necessidade de fralda)

3: Urge incontinência moderada (necessidade de fralda ou cateter quando fora de casa)

4: Uso de cateter ou fralda permanentes 